\title{
Effect of Organic and Chemical Fertilizer Application on Growth, Yield, and Quality of Small-Sized Tomatoes
}

\author{
Takamitsu Kai ${ }^{*}$, Shunya Nishimori ${ }^{2}$, Masahiko Tamaki ${ }^{1}$ \\ ${ }^{1}$ Kurokawa Field Science Center, Meiji University, Kawasaki, Japan \\ ${ }^{2}$ Department of Agriculture, School of Agriculture, Meiji University, Kawasaki, Japan \\ Email: ^kai_takamitsu@meiji.ac.jp
}

How to cite this paper: Kai, T., Nishimori, S. and Tamaki, M. (2020) Effect of Organic and Chemical Fertilizer Application on Growth, Yield, and Quality of Small-Sized Tomatoes. Journal of Agricultural Chemistry and Environment, 9, 121-133.

https://doi.org/10.4236/jacen.2020.93011

Received: July 14, 2020

Accepted: August 9, 2020

Published: August 12, 2020

Copyright $\odot 2020$ by author(s) and Scientific Research Publishing Inc. This work is licensed under the Creative Commons Attribution International License (CC BY 4.0).

http://creativecommons.org/licenses/by/4.0/

\begin{abstract}
Tomatoes in Japan are generally cultivated under management systems that use chemical fertilizers and synthetic chemical pesticides. However, the continuous use of these fertilizers and pesticides damages the soil environment and reduces the number of soil microorganisms. Organic farming has a relatively low environmental impact compared to conventional farming techniques, but typically has lower and more unstable yields. In this study, we investigated the effect of organic and chemical fertilizer application on growth, yield, and quality of small-sized (cherry) tomatoes. Cherry tomatoes were cultivated using organic and chemical organic fertilizers. Average weight and lateral diameter were significantly higher under organic fertilizer than under chemical fertilizer. In addition, shoot dry weight was significantly higher under organic fertilizer than chemical fertilizer. Lycopene content was significantly higher under organic fertilizer than chemical fertilizer. The total carbon (TC), total phosphorus (TP), total potassium (TK), available phosphoric (SP) and exchangeable potassium (SK) contents, $\mathrm{C} / \mathrm{N}$ ratio, and $\mathrm{pH}$ were significantly higher under organic fertilizer than chemical fertilizer. Bacterial biomass, nitrite $\left(\mathrm{NO}_{2}^{-}-\mathrm{N}\right)$ oxidation activity, nitrification $(\mathrm{N})$ circulation activity, and phosphoric $(\mathrm{P})$ circulation were higher under organic fertilizer than chemical fertilizer. From these results, the study indicates that appropriate controls such as TC, total nitrogen (TN), and $\mathrm{C} / \mathrm{N}$ ratio of organic fertilizer increased microbial biomass and enhanced nutrient circulation such as $\mathrm{N}$ circulation activity and $\mathrm{P}$ circulation activity. These results can be used to improve current organic farming practices and promote soil conservation.
\end{abstract}

\section{Keywords}

Small-Sized Tomato, Organic Fertilizer, Soil Microorganisms, Soil Fertility, Agricultural Environment, Environmental Conservation 


\section{Introduction}

The tomato (Solanum lycopersicon L.) is native to the Andes Highlands of South America. It is cultivated in temperate to tropical regions and is one of the most important vegetables globally [1]. Tomatoes are classified according to their use as either raw foods or processed foods. Further, raw tomatoes are classified into three types: large, medium, and small-sized (cherry), depending on the size of the fruits [2]. Among these, cherry tomato fruits contain protein, fat, carbohydrates, minerals (such as calcium, phosphorus, and iron), carotene, thiamine, nicotinic acid, riboflavin, and ascorbic acid [3]. Cherry tomatoes are also an important source for vitamins A and C, carotenoids, and lycopene [4]. Lycopene helps to reduce cancer risks [5] and protects the skin from ultraviolet radiation [6]. Carotenoids are useful against breast cancer and prostate cancer [7]. Tomato is ranked among the top five vegetables in terms of antioxidant activity [8].

Cherry tomatoes are cultivated mainly by conventional methods using chemical fertilizers and synthetic chemical pesticides. A recent report showed that only $1 \%$ of agricultural fields in the world are cultivated under organic farming systems [9]. Although the yield is relatively stable in conventional farming systems, excessive use of chemical fertilizers and synthetic chemical pesticides can cause severe environmental, socio-economic, and human health problems. As a result, consumer awareness towards organic foods has recently increased.

Organic farming methods cause relatively lower environmental damage compared with conventional farming and organic crop products are considered tasty and healthy [10]. Studies on tomato have also shown that antioxidants, flavonoids, sugar, and vitamin $\mathrm{C}$ are generally higher in organically grown fruits than conventionally grown fruits [11] [12] [13]. However, the yield is more unstable and/or lower in organic farming systems than conventional farming systems [14] [15] [16] [17]. Therefore, an updated organic farming system is required to ensure high yield and quality of agricultural products.

Soil microorganisms play several beneficial roles such as decomposing organic materials, releasing nutrients to plants, and bioremediation of pesticide polluted soils [18] [19] [20]. Therefore, soil microorganisms are considered key players in maintaining soil fertility. A large and active microorganism community is needed for efficient nutrient cycling and steady supply of nutrients to the plants.

In our previous study, we developed a soil fertility index, SOFIX, for the evaluation of soil fertility [21]. Analysis of the SOFIX data from several agricultural fields clearly showed that the number and activities of microorganisms can be significantly enhanced by controlling total carbon (TC) and total nitrogen (TN) contents. It has been found that excessive levels of TC, TN, total phosphorus (TP), and total potassium (TK) in conventional chemical fertilizer management system can lead to yield reduction in Japanese orchards [22]. Furthermore, apple orchards are relatively rich in TC, TN, TP, and TK compared with annual croplands such as paddy fields and uplands [23]. However, the relationship between microbial activities and plant growth remains unknown. The objective of this study is to indicate the effect of organic and chemical fertilizer application on 
growth, yield, and quality of cherry tomatoes.

\section{Materials and Methods}

\subsection{Experimental Treatments}

This study was carried out in a greenhouse at the Kurokawa Field Science Center, Meiji University, Kanagawa Prefecture, Japan. The test plants were cherry tomatoes "Benisuzume" treated in two experimental treatments where either organic fertilizer or chemical fertilizer was applied. Cherry tomato seedlings were purchased from Shinomoto Trading Co., Ltd. (Tokyo, Japan). The chemical experimental treatment was carried out using the chemical fertilizer plan recommended for cherry tomatoes $\left(\mathrm{N}_{2} \mathrm{P}_{2} \mathrm{O}_{5}: \mathrm{K}_{2} \mathrm{O}=180: 200: 180 \mathrm{~kg} \cdot \mathrm{ha}^{-1}\right)$ by Kanagawa Prefecture, Japan, and solid fertilizer was added to commercial black soil as the standard basal dressing [24]. The organic fertilizer is commercial cow dung compost ( $\mathrm{N}: \mathrm{P}: \mathrm{K}=2.7 \%: 2.9 \%: 2.6 \%$, cow dung compost, Tochigi, Japan). According to Nishio (2017) [25], the average total nitrogen concentration of cow dung compost is about $0.6 \%$ per piece of manure, which is about $15 \%$ of the total nitrogen concentration in the current year when it was applied. During the cropping period, usually $15 \%$ of it is gradually mineralized. Therefore, if 2 tons of cow manure compost is used per 10 areas, a total of $1.8 \mathrm{~kg}$ of nitrogen is gradually mineralized. In contrast, the nitrogen concentration of the inorganic nitrogen fertilizer, ammonium sulfate (ammonium sulfate), is about $21 \%$ of the Everything is inorganic. For example, when $50 \mathrm{~kg}$ of ammonium sulfate is applied per 10 areas, $10.5 \mathrm{~kg}$ of inorganic nitrogen is released. Therefore, $6.0 \mathrm{~g}$ of chemical fertilizer $\left(\mathrm{N}_{\mathrm{P}} \mathrm{P}_{2} \mathrm{O}_{5}: \mathrm{K}_{2} \mathrm{O}=6 \%: 40 \%: 6 \%\right.$, MAGAMP K, Osaka, Japan) and $89 \mathrm{~g}$ of organic fertilizer are well mixed into the black soil. It was applied by hand. The amount was adjusted accordingly and mixed with commercial black clay. No pesticides were applied in either treatment. One seedling was cultivated per 1/5000 a Wagner pot in both the chemical and organic fertilizer treatments. Four pots were prepared per treatment. Every two days, the pots were irrigated with $20 \mathrm{~mL}$ of water, which was sufficient to keep the soil surface moist but not cause any runoff from the pot. We used a single planting method for small tomatoes and compared harvesting, etc., in six-tiered bunches. The experiment was run for about 80 days total from planting until harvest.

\subsection{Cherry Tomato Cultivation}

Cherry tomato weight was measured with a gravimeter at each harvest. The yield was the sum of each weight and average weight was the total weight divided by the number of tomatoes. Tomato lateral and vertical diameter were measured using calipers; concurrently, the number of tomatoes at each harvest was counted.

\subsection{Cherry Tomato Plants}

After harvesting all the cherry tomatoes, shoots and roots were taken from each 
pot and washed carefully. The total dry weight of the shoots and roots in each pot was measured after oven drying at $80^{\circ} \mathrm{C}$ for three days until constant weight, giving four root and shoot dry weight measurements per treatment.

\subsection{Sugar and Lycopene Contents of Cherry Tomatoes}

The sugar content was analyzed using a pocket sugar meter (Model: PAL-S, Atago, Tokyo, Japan). Sugar content was determined by dropping undiluted tomato juice onto the sensor of the pocket sugar meter. Each tomato juice sample was measured three times, and the average was calculated. Lycopene content was measured immediately after harvesting the cherry tomatoes using a non-destructive measuring device (Fruit Selector, K-SS300-LC, Kubota Corporation) [26].

\subsection{Soil Chemical Properties}

Soil samples (top $15 \mathrm{~cm}$ layer, excluding the top $2-3 \mathrm{~cm}$ surface crust) were taken in each pot. The following chemical properties of the soil samples were analyzed: TC, TN, ammonium-nitrogen $\left(\mathrm{NH}_{4}^{+}-\mathrm{N}\right)$, nitrate-nitrogen $\left(\mathrm{NO}_{3}^{-}-\mathrm{N}\right)$, TP, available phosphoric acid (SP), TK, and exchangeable potassium (SK). The TC content was analyzed with a TOC analyzer (Model: SSM-5000A, Shimadzu, Kyoto, Japan). $\mathrm{NH}_{4}^{+}-\mathrm{N}$ and $\mathrm{NO}_{3}^{-}-\mathrm{N}$ were analyzed by extracting the soil sample with $1 \mathrm{M} \mathrm{KCl}$, followed by the indophenol blue and brucine methods [27]. To analyze the SP and SK, a soil-water suspension $(1: 20, w / v)$ was reciprocally shaken at $100 \mathrm{rpm}$ for $1 \mathrm{~h}$ and the extracts were analyzed using the molybdenum blue method [28] and atomic absorption spectrophotometry, respectively. The TN, TP, and TK contents were analyzed by digesting soils in a Kjeldahl Therm digestion unit (Gerhardt, Königswinter, Germany) with $\mathrm{H}_{2} \mathrm{SO}_{4}$ and $\mathrm{H}_{2} \mathrm{O}_{2} ; \mathrm{NH}_{4}^{+}-\mathrm{N}$, $\mathrm{SP}$, and SK contents in the digest were determined. The $\mathrm{pH}$ of the soil-water suspension (1:2.5, w/v) was analyzed using a $\mathrm{pH}$ meter (Model: LAQUA F-72, Horiba Scientific, Kyoto, Japan).

\subsection{Soil Biological Properties}

Nitrogen organic substances such as proteins are decomposed in soil into ammonia nitrogen $\left(\mathrm{NH}_{4}^{+}\right) \rightarrow$ nitrite nitrogen $\left(\mathrm{NO}_{2}^{-}\right) \rightarrow$ nitrate nitrogen $\left(\mathrm{NO}_{3}^{-}\right)$, and after protein $\rightarrow$ peptide $\rightarrow$ amino acid and low molecular weight are advanced by soil microorganisms. During these processes, $\mathrm{NH}_{4}^{+}$oxidation activity $\left(\mathrm{NH}_{4}^{+} \rightarrow\right.$ $\left.\mathrm{NO}_{2}^{-}\right), \mathrm{NO}_{2}^{-}$oxidation activity $\left(\mathrm{NO}_{2}^{-} \rightarrow \mathrm{NO}_{3}^{-}\right)$, and bacterial biomass were determined. Bacterial biomass was determined by eDNA analysis, which establishes an accurate and simple measurement by extracting microbial DNA from soil. $\mathrm{NH}_{4}^{+}$oxidation activity, $\mathrm{NO}_{2}^{-}$oxidation activity, and the number of microorganisms were quantified with a triangular radar chart, and the ability of soil to convert nitrogen organic matter to $\mathrm{NO}_{3}^{-}$was evaluated as " $\mathrm{N}$ circulation activity." The larger the area of the triangle, the more active the nitrogen circulation in the soil, and vice versa.

In addition, Phytic acid (organic phosphate) must be broken down into 
phosphate before the plant can absorb phosphate (phytic acid-degrading activity). Therefore, the ability to convert phytic acid into organic phosphate was evaluated as "P circulation activity."

Soils were assigned points: cases in which all phytic acid changed to phosphoric acid and there was no chemisorption with minerals were given 100 points, and cases in which phosphoric acid was not produced at all were given 0 points. However, a $\mathrm{P}$ circulation activity evaluation value of 100 points indicates that there is little mineral content. Therefore, soil with a moderate mineral content and abundant microorganism (due to phosphoric acid being supplied) was given 40 - 60 points.

The following biological properties were analyzed: total bacterial biomass, $\mathrm{NH}_{4}^{+}$ oxidation activity, $\mathrm{NO}_{2}^{-}$oxidation activity, $\mathrm{N}$ circulation activity, and $\mathrm{P}$ circulation activity. Total bacterial biomass was estimated by quantifying environmental DNA (eDNA) using the slow-stirring method [29]. The $\mathrm{N}$ circulation activity was analyzed using $\mathrm{NH}_{4}^{+}$and $\mathrm{NO}_{2}^{-}$oxidation activity values and total bacterial number, as described by Matsuno et al. (2013) [29] and Adhikari et al. (2014) [21]. P circulation activity was determined by analyzing the rate at which soluble $\mathrm{P}$ was released from phytic acid (a dominant form of organic $\mathrm{P}$ in soil) over a three-day incubation period [22] [23] [31].

\subsection{Statistical Analysis}

Data are presented as the mean \pm standard deviation (SD) values and analyzed using Bell Curve for Excel 2016 for Windows (Social Survey Research Information Co., Ltd., Tokyo, Japan). All data were analysed by using t-test, where appropriate. Different marks $\left.{ }^{*}\right)$ within a pot are significantly different at $p<0.05$, different marks $\left({ }^{*}\right)$ within a pot are different at $p<0.01$, and n.s. indicates no significant difference, according to the t-test method. All statistical analyses were conducted with a significance level of $\alpha=0.05(p<0.05)$.

\section{Results}

\subsection{Chemical and Biological Properties of the Black Soil}

Chemical property of the black soil is shown in Table 1 . The TC, TN, TP, TK content values of the black soil were 59,520, 2692, 677, and $1106 \mathrm{mg} \cdot \mathrm{kg}^{-1}$, respectively. $\mathrm{C} / \mathrm{N}$ ratio value of the black soil was 22.1. Furthermore, $\mathrm{NO}_{3}^{-}-\mathrm{N}, \mathrm{NH}_{4}^{+}-\mathrm{N}$, SP, and SK values of the black soil were 9.0, $0,12.0$, and $57.0 \mathrm{mg} \cdot \mathrm{kg}^{-1}$, respectively. In addition, $\mathrm{pH}$ was 5.5 . EC was $0.14 \mathrm{mS} \cdot \mathrm{cm}^{-1}$.

Biological property of the black soil is shown in Table 2. Bacterial biomass number value was not detected. $\mathrm{NH}_{4}^{+}-\mathrm{N}$ and $\mathrm{NO}_{2}^{-}-\mathrm{N}$ oxidation activity values were 7.0, and 27.0, respectively. $\mathrm{N}$ and $\mathrm{P}$ circulation activity values were 1.0 , and 0 points, respectively.

\subsection{Comparison of Weight, Length, Number, and Yield of Cherry Tomatoes}

Average weight, lateral and vertical diameter, set, and yield of the cherry 
Table 1. Chemical properties of black soil. ${ }^{2}$ Mean \pm standard deviation of a sample (TC, TN, TP, TK, $\mathrm{C} / \mathrm{N} \mathrm{ratio}, \mathrm{NO}_{3}^{-}-\mathrm{N}, \mathrm{NH}_{4}^{+}-\mathrm{N}$, SP, SK, $\mathrm{pH}$, and EC: $\mathrm{n}=4)$.

\begin{tabular}{|c|c|c|c|c|c|c|c|c|c|c|c|}
\hline & $\begin{array}{c}\text { Total C } \\
\left(\mathrm{mg} \cdot \mathrm{kg}^{-1}\right)\end{array}$ & $\begin{array}{c}\text { Total N } \\
\left(\mathrm{mg} \cdot \mathrm{kg}^{-1}\right)\end{array}$ & $\begin{array}{c}\text { Total P } \\
\left(\mathrm{mg} \cdot \mathrm{kg}^{-1}\right)\end{array}$ & $\begin{array}{c}\text { Total K } \\
\left(\mathrm{mg} \cdot \mathrm{kg}^{-1}\right)\end{array}$ & $\mathrm{C} / \mathrm{N}$ ratio & $\begin{array}{c}\mathrm{NO}_{3}^{-}-\mathrm{N} \\
\left(\mathrm{mg} \cdot \mathrm{kg}^{-1}\right)\end{array}$ & $\begin{array}{c}\mathrm{NH}_{4}^{+}-\mathrm{N} \\
\left(\mathrm{mg} \cdot \mathrm{kg}^{-1}\right)\end{array}$ & $\begin{array}{c}\text { Available } \\
\text { phosphoric } \\
\text { acid } \\
\left(\mathrm{mg} \cdot \mathrm{kg}^{-1}\right)\end{array}$ & $\begin{array}{c}\text { Exchangeable } \\
\text { potassium } \\
\left(\mathrm{mg} \cdot \mathrm{kg}^{-1}\right)\end{array}$ & $\mathrm{pH}$ & $\begin{array}{c}\mathrm{EC} \\
\left(\mathrm{mS} \cdot \mathrm{cm}^{-1}\right)\end{array}$ \\
\hline Black soil & $59,520 \pm 8.16^{z}$ & $2692 \pm 0.12$ & $677 \pm 1.63$ & $1106 \pm 2.45$ & $22.1 \pm 0.08$ & $9.0 \pm 0.8$ & $0 \pm 0.0$ & $12.0 \pm 2.45$ & $57 \pm 1.63$ & $5.5 \pm 0.1$ & $0.14 \pm 0.02$ \\
\hline
\end{tabular}

Table 2. Biological properties of black soil. ${ }^{\mathrm{z}}$ Mean \pm standard deviation of a sample (bacterial biomass, $\mathrm{NH}_{4}^{+}-\mathrm{N}$ oxidation activity, $\mathrm{NO}_{2}^{-}-\mathrm{N}$ oxidation activity, $\mathrm{N}$ circulation activity, and $\mathrm{P}$ circulation activity: $\mathrm{n}=4$ ).

\begin{tabular}{cccccc}
\hline & $\begin{array}{c}\text { Bacterial biomass } \\
\left(\times 10^{8} \text { cells } \cdot \mathrm{g}^{-1}\right)\end{array}$ & $\begin{array}{c}\mathrm{NH}_{4}^{+} \text {oxidation } \\
\text { activity (point) }\end{array}$ & $\begin{array}{c}\mathrm{NO}_{2}^{-} \text {oxidation } \\
\text { activity (point) }\end{array}$ & $\begin{array}{c}\mathrm{N} \text { circulation } \\
\text { activity (point) }\end{array}$ & $\begin{array}{c}\mathrm{P} \text { circulation } \\
\text { activity (point) }\end{array}$ \\
\hline Black soil & n.d $\pm 0^{\mathrm{z}}$ & $7.0 \pm 0.82$ & $27.0 \pm 1.63$ & $1.0 \pm 0$ & $0 \pm 0.0$ \\
\hline
\end{tabular}

tomatoes cultivated with organic and chemical fertilizer are shown in Table 3. Average weight values of the organic and chemical fertilizer were 5.0, and $3.1 \mathrm{~g}$, respectively. Lateral diameter values of the organic and chemical fertilizer were 19.4 , and $16.3 \mathrm{~mm}$, respectively. Vertical diameter values of the organic and chemical fertilizer were 21.1, and $18.2 \mathrm{~mm}$, respectively. Set values of the organic and chemical fertilizer were 16, and 11 number, respectively. Furthermore, yield of the organic and chemical fertilizer were 81.3 , and $32.6 \mathrm{~g}$, respectively. Overall, average weight, lateral diameter, vertical diameter, set, and yield values were the highest in organic farming orchards. Average weight and lateral and vertical diameter were significantly higher under organic fertilizer than chemical fertilizer. However, for set and yield, no significant difference was found.

\subsection{Comparison of Shoot and Underground, and Fresh and Dry Weight of Cherry Tomatoes Equations}

Shoot fresh and dry weight and root fresh and dry weight of cherry tomatoes are shown in Table 4. Shoot fresh weight values of the organic and chemical fertilizer were 11.3, and $25.9 \mathrm{~g}$, respectively. Shoot dry weight values of the organic and chemical fertilizer were 3.1, and $5.2 \mathrm{~g}$, respectively. Root fresh weight values of the organic and chemical fertilizer were 4.4 , and 4.9 g, respectively. Furthermore, root dry weight values of the organic and chemical fertilizer were 0.7 , and $0.8 \mathrm{~g}$, overall, shoot fresh weight, shoot dry weight, root fresh weight, and root dry weight were the highest in chemical farming orchards. Shoot fresh and dry weight were significantly higher under chemical fertilizer than organic fertilizer. However, root fresh weight, and root dry weight, no significant difference was found. It is considered that the quick-acting fertilizer greatly affected the shoots and roots of cherry tomato plants.

\subsection{Comparison of Sugar Content and Lycopene of Cherry Tomatoes}

Sugar content and lycopene of cherry tomatoes are shown in Table 5. The average sugar content under organic fertilizer was $8.18{ }^{\circ}$ Brix, compared with 7.69 
Table 3. Average tomato weight, tomato lateral diameter, tomato vertical diameter, tomato set, and yield of cherry tomatoes. ${ }^{\mathrm{z}}$ Mean \pm standard deviation of a sample (average tomato weight, tomato lateral diameter, tomato vertical diameter, tomato set, and yield: $\mathrm{n}$ $=32-49) .{ }^{y}$ Different marks $\left({ }^{*}\right)$ within a pot are significantly different at the $p<0.05$, different marks $\left({ }^{*}\right)$ within a pot are different at the $p<0.01$, and n.s. indicates no significant difference, according to the t-test method.

\begin{tabular}{|c|c|c|c|c|c|}
\hline & $\begin{array}{l}\text { Average weight } \\
\text { (g) }\end{array}$ & $\begin{array}{c}\text { Lateral } \\
\text { diameter }(\mathrm{mm})\end{array}$ & $\begin{array}{c}\text { Vertical } \\
\text { diameter }(\mathrm{mm})\end{array}$ & $\begin{array}{c}\text { Set } \\
\text { (number) }\end{array}$ & $\begin{array}{l}\text { Yield } \\
(\mathrm{g})\end{array}$ \\
\hline Organic fertilizer & $5.0 \pm 1.10^{z} \quad$ ** $y$ & $19.4 \pm 1.68$ & $21.1 \pm 2.04$ & $16 \pm 8$ n.s. & $81.3 \pm 30.8 \mathrm{n}$ \\
\hline Chemical fertilizer & $3.1 \pm 0.75$ & $16.3 \pm 1.79$ & $18.2 \pm 1.27$ & $11 \pm 5$ & $32.6 \pm 22.8$ \\
\hline
\end{tabular}

Table 4. Shoot fresh weight, shoot dry weight, root fresh weight, and root dry weight of cherry tomatoes. ${ }^{\mathrm{z}}$ Mean \pm standard deviation of a sample (shoot fresh weight, shoot dry weight, root fresh weight, and root dry weight: $\mathrm{n}=4$ ). ${ }^{\mathrm{y}}$ Different marks $\left({ }^{\star}\right)$ within a pot are significantly different at the $p<0.05$, different marks $\left({ }^{*}\right)$ within a pot are different at the $p<0.01$, and n.s. indicates no significant difference, according to the t-test method.

\begin{tabular}{|c|c|c|c|c|}
\hline & $\begin{array}{l}\text { Shoot fresh weight } \\
(\mathrm{g})\end{array}$ & $\begin{array}{l}\text { Shoot dry weight } \\
\text { (g) }\end{array}$ & $\begin{array}{l}\text { Root fresh weight } \\
\text { (g) }\end{array}$ & $\begin{array}{l}\text { Root dry weight } \\
\text { (g) }\end{array}$ \\
\hline Organic fertilizer & $11.3 \pm 7.84$ & $3.1 \pm 0.62$ & $4.4 \pm 2.58$ & $0.7 \pm 0.26$ \\
\hline Chemical fertilizer & $25.9 \pm 13.1$ & $5.2 \pm 1.04$ & $4.9 \pm 0.65$ & $0.8 \pm 0.16$ \\
\hline
\end{tabular}

Table 5. Sugar content, and lycopene of small-sized tomatoes. ${ }^{\mathrm{z}}$ Mean \pm standard deviation of a sample (sugar content: $\mathrm{n}=13-49$, and lycopene: $\mathrm{n}=8-28$ ). ${ }^{\mathrm{y}}$ Different marks $\left(^{*}\right)$ within a pot are significantly different at the $p<0.05$, different marks $\left({ }^{*}\right)$ within a pot are different at the $p<0.01$, and n.s. indicates no significant difference, according to the t-test method.

\begin{tabular}{|c|c|c|c|c|c|}
\hline & \multicolumn{2}{|c|}{ Sugar content $\left({ }^{\circ}\right.$ Brix $)$} & & \multicolumn{2}{|c|}{ Lycopene (mg.100 g $\left.\mathrm{g}^{-1}\right)$} \\
\hline Organic fertilizer & $8.18 \pm 1.33$ & \multirow{2}{*}{ n.s. } & \multirow{2}{*}{$\mathrm{y}$} & $8.44 \pm 1.09$ & \\
\hline Chemical fertilizer & $7.69 \pm 0.78$ & & & $7.00 \pm 1.46$ & \\
\hline
\end{tabular}

${ }^{\circ}$ Brix under chemical fertilizer. The sugar content was about $0.6 \%$ higher under organic fertilizer than chemical fertilizer, but no significant difference was found. Generally, tomatoes have a sugar content of 4 to $5{ }^{\circ} \mathrm{Brix}$, and a sugar content of $8{ }^{\circ}$ Brix or more is considered to be extremely sweet [24]. Therefore, the organically cultivated cherry tomatoes in our study were very sweet. Lycopene values of the organic and chemical fertilizer were 8.44 , and $7.00 \mathrm{mg} \cdot 100 \mathrm{~g}^{-1}$. Lycopene content under organic fertilizer was significantly higher than chemical fertilizer. The word "data" is plural, not singular.

\subsection{Comparison of Soil Chemical Properties}

The soil chemical properties of the cherry tomato soils in pots under organic and chemical fertilizer systems are shown in Table 6. TC content values of the organic and chemical fertilizer were 27,802 , and $19,119 \mathrm{mg} \cdot \mathrm{kg}^{-1}$, respectively. TN content values of the organic and chemical fertilizer were 1616, and 1793 $\mathrm{mg} \cdot \mathrm{kg}^{-1}$, respectively. TP content values of the organic and chemical fertilizer 
Table 6. Soil chemical properties. ${ }^{2}$ Mean \pm standard deviation of a sample (TC, TN, TP, TK, C/N ratio, $\mathrm{NO}_{3}^{-}-\mathrm{N}, \mathrm{NH}_{4}^{+}-\mathrm{N}, \mathrm{SP}, \mathrm{SK}$, $\mathrm{pH}$, and EC: $\mathrm{n}=4)$. ${ }^{\mathrm{y}}$ Different marks $\left({ }^{*}\right)$ within a pot are significantly different at the $p<0.05$, different marks $\left(^{* *}\right)$ within a pot are different at the $p<0.01$, and n.s. indicates no significant difference, according to the t-test method.

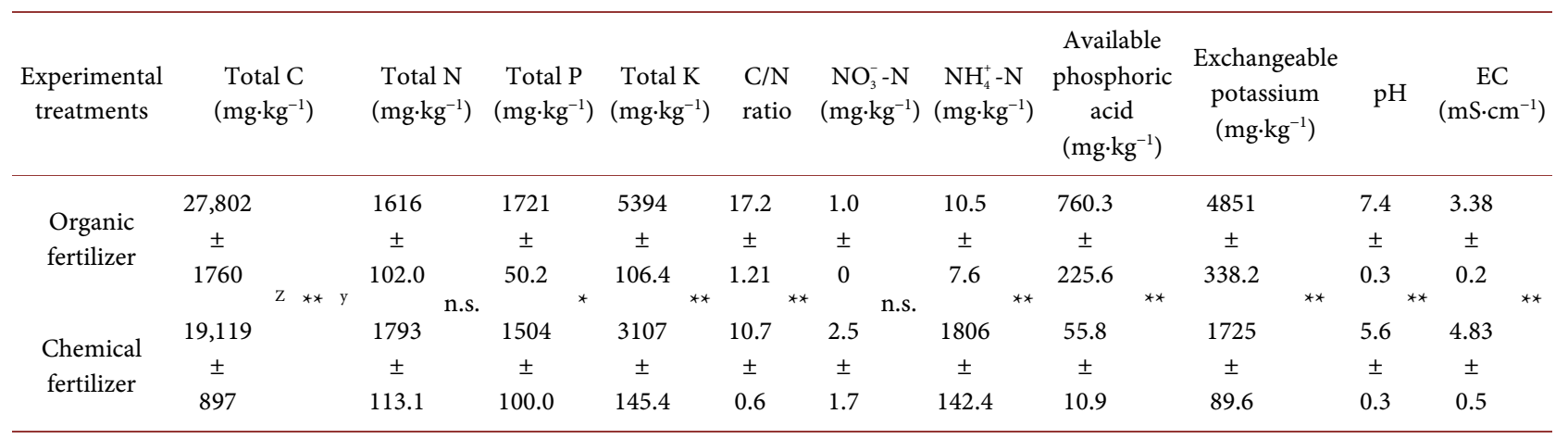

were 1721 , and $1504 \mathrm{mg} \cdot \mathrm{kg}^{-1}$, respectively. TK content values of the organic and chemical fertilizer were 5394 , and $3107 \mathrm{mg} \cdot \mathrm{kg}^{-1}$, respectively. $\mathrm{C} / \mathrm{N}$ ratio values of the organic and chemical fertilizer were 17.2, and 10.7, respectively. $\mathrm{NO}_{3}^{-}-\mathrm{N}$ content values of the organic and chemical fertilizer were 1.0, and 2.5, respectively. $\mathrm{NH}_{4}^{+}-\mathrm{N}$ content values of the organic and chemical fertilizer were 10.5, and 1806, respectively. SP content values of the organic and chemical fertilizer were 760.3 , and $55.8 \mathrm{mg} \cdot \mathrm{kg}^{-1}$, respectively. SK content values of the organic and chemical fertilizer were 4851 , and $1725 \mathrm{mg} \cdot \mathrm{kg}^{-1}$, respectively. $\mathrm{pH}$ values of the organic and chemical fertilizer were 7.4, and 5.6, respectively. Furthermore, EC values of the organic and chemical fertilizer were 3.38 , and $4.83 \mathrm{mS} \cdot \mathrm{cm}^{-1}$, respectively. The TC, TK, SP, and SK contents, $\mathrm{C} / \mathrm{N}$ ratio, and $\mathrm{pH}$ were significantly higher under organic fertilizer than chemical fertilizer. In addition, the TP content was higher under organic fertilizer than chemical fertilizer. Conversely, the $\mathrm{NH}_{4}^{+}-\mathrm{N}$ content and EC were significantly higher under chemical fertilizer than organic fertilizer, but no significant difference was found in $\mathrm{TN}$ and $\mathrm{NO}_{3}^{-}-\mathrm{N}$.

\subsection{Comparison of Soil Chemical Properties}

Biological properties of the cherry tomato soils in pots under organic and chemical fertilizer systems are shown in Table 7. Bacterial biomass number values of the organic and chemical fertilizer were $18.6 \times 10^{8}$ cells $\mathrm{g}^{-1}$, and not detected, respectively. $\mathrm{NH}_{4}^{+}-\mathrm{N}$ oxidation activity values of the organic and chemical fertilizer were 60.8 , and 83.0 point, respectively. $\mathrm{NO}_{2}^{-}-\mathrm{N}$ oxidation activity values of the organic and chemical fertilizer were 69.5 , and 32.3 point, respectively. The radar charts of average $\mathrm{N}$ circulation activity from the organic and chemical fertilizer treatments in cherry tomato soils are shown in Figure 1. N circulation activity values of the organic and chemical fertilizer were 55.8 , and 8.8 point, respectively. Furthermore, average $\mathrm{P}$ circulation activity from the organic and chemical fertilizer treatments in cherry tomato soils are shown in Figure 2. P circulation activity values of the organic and chemical fertilizer were 15.0, and not detected, respectively. Bacterial biomass, $\mathrm{N}$ circulation activity, and $\mathrm{P}$ circulation activity were significantly higher under organic fertilizer than chemical 
Bacterial biomass

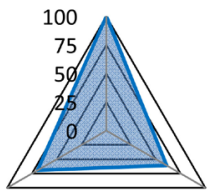

$\mathrm{NO}_{2}^{-}$oxidation activity

$\mathrm{NH}_{4}^{+}$oxidation activity

Average $\mathrm{N}$ circulation activity 55.8 points

(a)
Bacterial biomass

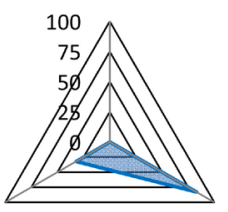

$\mathrm{NO}_{2}^{-}$oxidation activity

$\mathrm{NH}_{4}^{+}$oxidation activity

(b)

Figure 1. Radar chart of $\mathrm{N}$ circulation activity using (a) organic fertilizer; (b) chemical fertilizer.

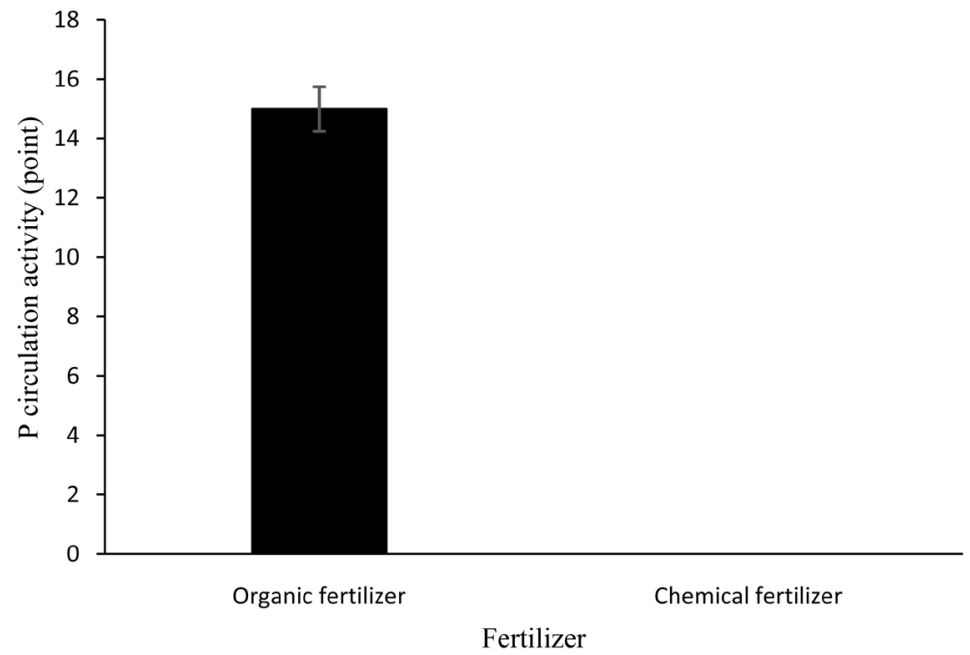

Figure 2. Average $\mathrm{P}$ circulation activity.

Table 7. Soil biological properties. ${ }^{2}$ Mean \pm standard deviation of a sample (bacterial biomass, $\mathrm{NH}_{4}^{+}-\mathrm{N}$ oxidation activity, $\mathrm{NO}_{2}^{-}-\mathrm{N}$ oxidation activity, $\mathrm{N}$ circulation activity, and P circulation activity: $\mathrm{n}=4)$. ${ }^{\mathrm{y}}$ Different marks $\left({ }^{*}\right)$ within a pot are significantly different at the $p<0.05$, different marks $\left.{ }^{* *}\right)$ within a pot are different at the $p<0.01$, and n.s. indicates no significant difference, according to the t-test method.

\begin{tabular}{|c|c|c|c|c|c|}
\hline $\begin{array}{c}\text { Experimental } \\
\text { treatments }\end{array}$ & $\begin{array}{c}\text { Bacterial } \\
\text { biomass } \\
\left(\times 10^{8}{\left.\text { cells } \mathrm{g}^{-1}\right)}^{-1}\right.\end{array}$ & $\begin{array}{c}\mathrm{NH}_{4}^{+} \text {oxidation } \\
\text { activity } \\
\text { (point) }\end{array}$ & $\begin{array}{c}\mathrm{NO}_{2}^{-} \text {oxidation } \\
\text { activity } \\
\text { (point) }\end{array}$ & $\begin{array}{l}\mathrm{N} \text { circulation } \\
\text { activity } \\
\text { (point) }\end{array}$ & $\begin{array}{l}\text { P circulation } \\
\text { activity } \\
\text { (point) }\end{array}$ \\
\hline $\begin{array}{l}\text { Organic } \\
\text { fertilizer }\end{array}$ & $18.6 \pm 4.54^{\mathrm{z}}$ & $60.8 \pm 28.5$ & $69.5 \pm 23.1$ & $55.8 \pm 11.2$ & $15.0 \pm 1.7$ \\
\hline $\begin{array}{l}\text { Chemical } \\
\text { fertilizer }\end{array}$ & n.d & $83.0 \pm 17.6$ & $32.3 \pm 1.5$ & $8.8 \pm 1.6$ & n.d \\
\hline
\end{tabular}

fertilizer. $\mathrm{N}$ circulation activity under organic fertilizer was about six times higher than under chemical fertilizer. Moreover, $\mathrm{NO}_{2}^{-}-\mathrm{N}$ oxidation activity was higher under organic fertilizer than chemical fertilizer. Conversely, the $\mathrm{NH}_{4}^{+}-\mathrm{N}$ oxidation activity value was higher under chemical fertilizer than organic fertilizer, no significant difference was found in $\mathrm{NH}_{4}^{+}-\mathrm{N}$ oxidation activity. 


\section{Discussion}

Kubo et al. (2017) [32] reported that the recommended carbon and nitrogen contents and $\mathrm{C} / \mathrm{N}$ ratio are $25,000 \mathrm{mg} \cdot \mathrm{kg}^{-1}$ or higher, $1500 \mathrm{mg} \cdot \mathrm{kg}^{-1}$ or higher, and $10-25$, respectively. In our study, these recommended values were reached in all pots under organic fertilizer methods. Contrarily, in the chemical fertilizer treatment, the soils may have lacked TC because little TC is in the fertilizer.

In this study, we investigated the effect of organic and chemical fertilizer application on growth, yield, and quality of small-sized cherry tomatoes. Cherry tomatoes were cultivated in chemically and organically fertilized experimental pots. The average weight and lateral diameter were significantly higher under organic fertilizer than chemical fertilizer. Furthermore, the shoot dry weight was significantly higher under organic fertilizer than chemical fertilizer. Lycopene was significantly higher under organic fertilizer than chemical fertilizer. The TC, $\mathrm{TP}, \mathrm{TK}, \mathrm{SP}$, and $\mathrm{SK}$ contents, $\mathrm{C} / \mathrm{N}$ ratio, and $\mathrm{pH}$ were significantly higher under organic fertilizer than chemical fertilizer. In addition, bacterial biomass, $\mathrm{NO}_{2}^{-}-\mathrm{N}$ oxidation activity, $\mathrm{N}$ circulation activity, and $\mathrm{P}$ circulation were also higher under organic fertilizer than chemical fertilizer.

Appropriate controls such as $\mathrm{TC}, \mathrm{TN}$, and the $\mathrm{C} / \mathrm{N}$ ratio of organic fertilizer increased microbial biomass and enhanced nutrient circulation such as $\mathrm{N}$ and $\mathrm{P}$ circulation activity. These results can be used to improve current organic farming practices and promote soil conservation.

\section{Conclusion}

Tomatoes in Japan are generally cultivated under management systems that use chemical fertilizers and synthetic chemical pesticides. However, the continuous use of these fertilizers and pesticides damages the soil environment and reduces the number of soil microorganisms. Organic farming has a relatively low environmental impact compared to conventional farming techniques, but typically has lower and more unstable yields. In this study, the yield, sugar content and lycopene of tomatoes grown with organic fertilizers were higher than those of tomatoes grown with chemical fertilizers. Appropriate controls such as TC, TN, and the $\mathrm{C} / \mathrm{N}$ ratio of organic fertilizer increased microbial biomass and enhanced nutrient circulation such as $\mathrm{N}$ and $\mathrm{P}$ circulation activity. These results can be used to improve current organic farming practices and promote soil conservation.

\section{Acknowledgements}

The submission of this paper was funded by the Meiji University Research Grant for Individuals. We would like to thank them for their support.

\section{Conflicts of Interest}

The authors declare no conflicts of interest regarding the publication of this paper. 


\section{References}

[1] Food and Agricultural Organization of the United Nations (2014) FAOSTAT: Crop Data. http://www.fao.org/faostat/en/\#data/QC

[2] Nukaya, A. (2014) Basics of Vegetable Horticulture, Agricultural Cooperative. 76.

[3] Duke, J.A. and Ayensu, E.S. (1985) Medicinal Plants of China. Reference Publications, Algonac.

[4] Sánchez-Moreno, C., Plaza, L., De Ancos, B. and Cano, M.P. (2006) Nutritional Characterisation of Commercial Traditional Pasteurised Tomato Juices: Carotenoids, Vitamin C and Radical-Scavenging Capacity. Food Chemistry, 98, 749-756. https://doi.org/10.1016/j.foodchem.2005.07.015

[5] Kucuk, O. (2001) Phase II Randomized Clinical Trial of Lycopene Supplementation before Radical Prostatectomy. Cancer Epidemiology, Biomarkers \& Prevention, 10, 861-868.

[6] Piccardi, N. and Manissier, P. (2009) Nutrition and Nutritional Supplementation: Impact on Skin Health and Beauty. Dermato-Endocrinology, 1, 271-274.

https://doi.org/10.4161/derm.1.5.9706

[7] Singh, J.S., Pandey, V.C. and Singh, D.P. (2011) Efficient Soil Microorganisms: A New Dimension for Sustainable Agriculture and Environmental Development. Agriculture, Ecosystems \& Environment, 140, 339-353. https://doi.org/10.1016/j.agee.2011.01.017

[8] Easdown, W. and Kalb, T. (2004) Antioxidant Capacities and Daily Antioxidant Intake from Vegetables Consumed in Taiwan. AVRDC Progress Report, Asian Vegetable Research and Development Center, Shanhua.

[9] FiBL and IFOAM (2017) The World of Organic Agriculture Statistics and Emerging Trends, 2017. Research Institute of Organic Agriculture FiBL and IFOAM-Organics International. http://www.organic-world.net/yearbook/yearbook-2017.html

[10] Woese, K., Lange, D., Boess, C. and Bogl, K.W. (1997) A Comparison of Organically and Conventionally Grown Foods-Results of a Review of the Relevant Literature. Journal of the Science of Food and Agriculture, 74, 281-293.

https://doi.org/10.1002/(SICI)1097-0010(199707)74:3\%3C281::AID-JSFA794\%3E3. $\underline{0 . \mathrm{CO} ; 2-\mathrm{Z}}$

[11] Chassy, A.W., Bui, L., Renaud, E.N., Van Horn, M. and Mitchell, A.E. (2006) Three-Year Comparison of the Content of Antioxidant Microconstituents and Several Quality Characteristics in Organic and Conventionally Managed Tomatoes and Bell Peppers. Journal of Agricultural and Food Chemistry, 54, 8244-8252. https://doi.org/10.1021/jf060950p

[12] Mitchell, A.E., Hong, Y.-J., Koh, E., Barrett, D.M., Bryant, D.E., Denison, R.F. and Kaffka, S. (2007) Ten-Year Comparison of the Influence of Organic and Conventional Crop Management Practices on the Content of Flavonoids in Tomatoes. Journal of Agricultural and Food Chemistry, 55, 6154-6159. https://doi.org/10.1021/jf070344+

[13] Vallverdú-Queralt, A., Jáuregui, O., Medina-Remón, A. and Lamuela-Raventos, R.M. (2012) Evaluation of a Method to Characterize the Phenolic Profile of Organic and Conventional Tomatoes. Journal of Agricultural and Food Chemistry, 60, 3373-3380. https://doi.org/10.1021/jf204702f

[14] Mäder, P., Fliessbach, A., Dubois, D., Gunst, L., Fried, P. and Niggli, U. (2002) Soil Fertility and Biodiversity in Organic Farming. Science, 296, 1694-1697.

https://doi.org/10.1126/science. 1071148 
[15] Vallverdú-Queralt, A., Jáuregui, O., Medina-Remón, A. and Lamuela-Raventos, R.M. (2012) Evaluation of a Method to Characterize the Phenolic Profile of Organic and Conventional Tomatoes. Journal of Agricultural and Food Chemistry, 60, 3373-3380. https://doi.org/10.1021/jf204702f

[16] De Ponti, T., Rijk, B. and Van Ittersum, M.K. (2012) The Crop Yield Gap between Organic and Conventional Agriculture. Agricultural Systems, 108, 1-9. https://doi.org/10.1016/j.agsy.2011.12.004

[17] Seufert, V., Ramankutty, N. and Foley, J.A. (2012) Comparing the Yields of Organic and Conventional Agriculture. Nature, 485, 229-232. https://doi.org/10.1038/nature11069

[18] Singh, J.S., Pandey, V.C. and Singh, D.P. (2011) Efficient Soil Microorganisms: A New Dimension for Sustainable Agriculture and Environmental Development. Agriculture, Ecosystems and Environment, 140, 339-353. https://doi.org/10.1016/j.agee.2011.01.017

[19] Chen, M., Xu, P., Zeng, G., Yang, C., Huang, D. and Zhang, J. (2015) Bioremediation of Soils Contaminated with Polycyclic Aromatic Hydrocarbons, Petroleum, Pesticides, Chlorophenols and Heavy Metals by Composting: Applications, Microbes and Future Research Needs. Biotechnology Advances, 33, 745-755 https://doi.org/10.1016/j.biotechadv.2015.05.003

[20] Adhikari, D., Perwira, I.Y., Araki, K.S. and Kubo, M. (2016) Stimulation of Soil Microorganisms in Pesticide-Contaminated Soil Using Organic Materials. AIMS Bioengineering, 3, 379-388. https://doi.org/10.3934/bioeng.2016.3.379

[21] Adhikari, D., Kai, T., Mukai, M., Araki, K.S. and Kubo, M. (2014) A New Proposal for a Soil Fertility Index (SOFIX) for Organic Agriculture and Development of a SOFIX Database for Agricultural Fields. Current Topics in Biotechnology, 8, 81-91.

[22] Kai, T., Mukai, M., Araki, K.S., Adhikari, D. and Kubo, M. (2015) Physical and Biological Properties of Apple Orchard Soils of Different Productivities. Open Journal of Soil Science, 5, 149-156. https://doi.org/10.4236/ojss.2015.57015

[23] Kai, T., Mukai, M., Araki, K.S., Adhikari, D. and Kubo, M. (2016) Analysis of Chemical and Biological Soil Properties in Organically and Conventionally Fertilized Apple Orchards. Journal of Agricultural Chemistry and Environment, 5, 92-99. https://doi.org/10.4236/jacen.2016.52010

[24] Kanagawa Prefecture Agricultural Research Institute (2002) Which Varieties Are Suitable for High Sugar Content in Tomato Cultivation? Kanagawa Prefecture Agricultural Research Institute. https://www.pref.kanagawa.jp/docs/cf7/cnt/f450010/p582114.html

[25] Nishio, M. (2017) Organic Agriculture. Nobunkyo, 20-32.

[26] Ito, H. and Morimoto, S. (2009) Possibility of Nondestructive Measurement of Lycopene in Tomato Using Visible and Near-Infrared Spectroscopy. Illuminating Engineering Society, 93, 510-513.

[27] Donald Nicholas, D.J. and Nason, A. (1957) Determination of Nitrate and Nitrite. Methods in Enzymology, 3, 981-984. https://doi.org/10.1016/S0076-6879(57)03489-8

[28] Murphy, J. and Riley, J.P. (1962) A Modified Single Solution Method for the Determination of Phosphate in Natural Waters. Analytica Chimica Acta, 27, 31-36. https://doi.org/10.1016/S0003-2670(00)88444-5

[29] Aoshima, H., Kimura, A., Shibutani, A., Okada, C., Matsumiya, Y. and Kubo, M. (2006) Evaluation of Soil Bacterial Biomass Using Environmental DNA Extracted by Slow-Stirring Method. Applied Microbiology and Biotechnology, 71, 875-880. 
https://doi.org/10.1007/s00253-005-0245-x

[30] Matsuno, T., Horii, S., Sato, T., Matsumiya, Y. and Kubo, M. (2013) Analysis of Nitrification in Agricultural Soil and Improvement of Nitrogen Circulation with Autotrophic Ammonia-Oxidizing Bacteria. Applied Microbiology and Biotechnology, 169, 795-809. https://doi.org/10.1007/s12010-012-0029-6

[31] Horii, S., Matsuno, T., Tagomori, J., Mukai, M., Adhikari, D. and Kobo, M. (2013) Isolation and Identification of Phytate-Degrading Bacteria and Their Contribution to Phytate Mineralization in Soil. Journal of General and Applied Microbiology, 59, 353-360.

[32] Kubo, M., Adhikari, D., Araki, S.K., Kubota, K., Shinozaki, A., Matsuda, F., Mitsukoshi, K., Mukai, M. and Watarai, H. (2017) Science of Soil Making. Sibundo Shinkosha Co., Tokyo, 2-185. 